\title{
SUSTAINABLE DEVELOPMENT: A CONCEPTUAL FRAMEWORK FOR THE TECHNOLOGY MANAGEMENT FIELD OF KNOWLEDGE AND A DEPARTURE FOR FURTHER RESEARCH
}

\author{
A.C. Brent ${ }^{1,2}$ and M.W. Pretorius ${ }^{1}$ \\ ${ }^{1}$ Graduate School of Technology Management \\ University of Pretoria, South Africa \\ tinus.pretorius@up.ac.za \\ ${ }^{2}$ Resource Based Sustainable Development \\ Natural Resources and the Environment \\ CSIR, South Africa \\ alan.brent@up.ac.za
}

\begin{abstract}
The complexity of integrating the concept of sustainable development and the reality of technology or innovation management practices has been argued. The primary objective is to introduce a conceptual framework of technology management knowledge, and coupled tools and methodologies, as it relates to sustainable development. Furthermore, a criteria framework of sustainable development is established, and insight is provided into how sustainability aspects may be measured effectively as part of technology management practices. From a literature review, it is concluded that sustainability aspects are not addressed adequately in technology management theories and practices. The subsequent conceptual framework defines the context better in which sustainable technology management should occur. Emerging technology management practices related to sustainable development do emphasise the focus on technology strategy, selection and transfer, especially between developed and emerging economies. At the core of these issues lies technology assessment. As a departure point for further research it is therefore recommended to concentrate on the development of technology assessment methods that incorporate the dynamic interactions between nature and society that is researched in the emerging field of sustainability science.
\end{abstract}

\section{OPSOMMING}

Die kompleksiteit om die konsep van volhoubare ontwikkeling te integreer in praktyke van tegnologie- en innovasiebestuur word uitgelig. Die primêre doel is om ' $n$ konseptuele raamwerk daar te stel om die verhouding van tegnologiebestuur tot volhoubare ontwikkeling te toon. Verder word 'n raamwerk van volhoubare ontwikkelingskriteria voorgestel, en insigte gegee van hoe sulke aspekte effektief gemeet kan word as deel van tegnologiebestuurpraktyke. 'n Literatuurstudie beaam dat dié aspekte onvoldoende in tegnologiebestuurteorie en -praktyke aangespreek word. Die raamwerk definieer die konteks beter waarin volhoubare tegnologiebestuur moet plaasvind. Nuwe tegnologiebestuurpraktyke relevant tot volhoubare ontwikke-ling, fokus op tegnologiestrategie, -seleksie en -oordrag. Die kern hiervan is tegnolo-gie-assessering. Dus word voorgestel dat verdere navorsing fokus op die ontwikkeling van tegnologieassesseringmetodes wat die dinamiese interaksie tussen die natuur en die samelewing insluit soos nagevors word in die nuwe veld van volhoubaarheid. 


\section{INTRODUCTION}

The report of the World Commission on Environment and Development (WCED) in 1987 is viewed as a major political turning point for the concept of sustainable development [1]. Since then the influence of the concept has increased extensively and it features more and more as a core element in policy documents of governments and international agencies [1]. The World Summit on Sustainable Development (WSSD) in 2002 highlighted this growing recognition of the concept by governments as well as businesses at a global level [2]. This need to incorporate the concept of sustainable development into decision-making, combined with the World Bank three-pillar-approach to sustainable development [3], resulted in the popular business term "triple-bottom-line decision-making".

The concept of sustainability and sustainable development may be understood intuitively, but it remains difficult to express in concrete, operational terms [4]. However, many agree that sustainable development is about achieving environmental, economic, and social welfare for present as well as future generations [5]. From a governmental perspective this can be at national and global levels [6]. From an organizational perspective this can be at project [7] and technology [8, 9] levels. In some cases stakeholders specifically require that environmental, economic, and social goals must be met across all levels of development. Sustainable development has subsequently been conceptualised as a state of dynamic equilibrium between societal demand for a preferred development and the supply of environmental and economic goods and services needed to meet this demand [4]. Systems approaches have been proposed to consider strategic sustainable development planning in different sectors [10, 11]. But the intricate relationships between the three dimensions of sustainable development, i.e. environmental, economic and social welfare, have been difficult to model within the concept of a clear absolute technological system [8, 9]. Specifically, trade-offs between the three dimensions of sustainable development may not be possible to quantify as the benefits cannot be measured. Proposals for these trade-offs can be referred to as 'weak', i.e. indirectly indicating sustainability [12, 13, 14].

Consensus on the general objectives and basic principles of sustainable development may be obtained in theory. But consensus on the details of how to achieve sustainable development or maintain sustainability is difficult to obtain in practice. This difficulty can be attributed to the variety of perceptions on specific sociocultural and political contexts that change over time [4, 15]. To this end, the complexity of integrating the concept of sustainable development and the reality of technology or innovation management practices has been argued [16]. The problem lies with the required amalgamation of the:

- $\quad$ Traditional sustainability sciences of environmental and social assessment, and the associated Integrated Environmental Management tools.

- Conventional and resource- or environmental-focused economic sciences, and the associated tools such as Life Cycle Costing.

- $\quad$ The technology management theories and associated applications such as technology forecasting and roadmapping, and transfer. 
From a research perspective the following main question was subsequently posed: Are sustainability aspects addressed adequately in technology management theories and practices? In other words, has technological research progressed into the field of sustainability science, as has been suggested [17]? The research question focuses on mainly large-scale technologies, i.e. technologies that can only be added in discreet sized lumps [18], and which are highly dependent on, or may pose risks to, the natural resource base of countries and regions [19].

\subsection{Objectives of this paper}

The primary objective of this paper is to introduce a conceptual framework of the technology management field of knowledge, and coupled tools and methodologies, as it relates to sustainable development. The secondary objectives are to establish a criteria framework of what sustainable development entails, and to provide insight into how sustainability aspects may be measured effectively as part of technology management practices.

From these objectives the paper aims to identify the departure point for further research in terms of incorporating the concept of sustainable development into the technology management field of knowledge, which is a specific agenda that may differ significantly from other technology management orientated research themes [20].

\section{RESEARCH APPROACH}

The primary objective of the paper was addressed by first considering the:

- $\quad$ Management of Technology (MOT) body-of-knowledge (BoK) process (see Fig. 1 ), which has been initiated by the International Association for Management of Technology (IAMOT) [21], and specifically a survey on a Template for Graduate Programs and an analysis of the results of a survey of 148 Technology Management or MOT graduate programs [22].

- $\quad$ Related research areas identified by the Engineering and Technology Management Education and Research Council (ETMERC) [23].

The Technovation journal was first selected as it is the official IAMOT journal; ETMERC does not have an official journal at present. The Technovation journal was searched for papers relating to tools and methodologies of technology management in general, and on sustainable development, but relating to technology management. The keywords of 'technology management tools', 'technology management methodology' and 'sustainable development' were used in the review (see Table 1). Furthermore, a boolean search was conducted in multiple journal databases for the keywords 'technology management' and 'sustainable development' for publications that link the two fields. Table 1 summarises the journals that have published papers relating to technology management theories and practices, and technology management orientated sustainable development, and the databases that have revealed the results. 


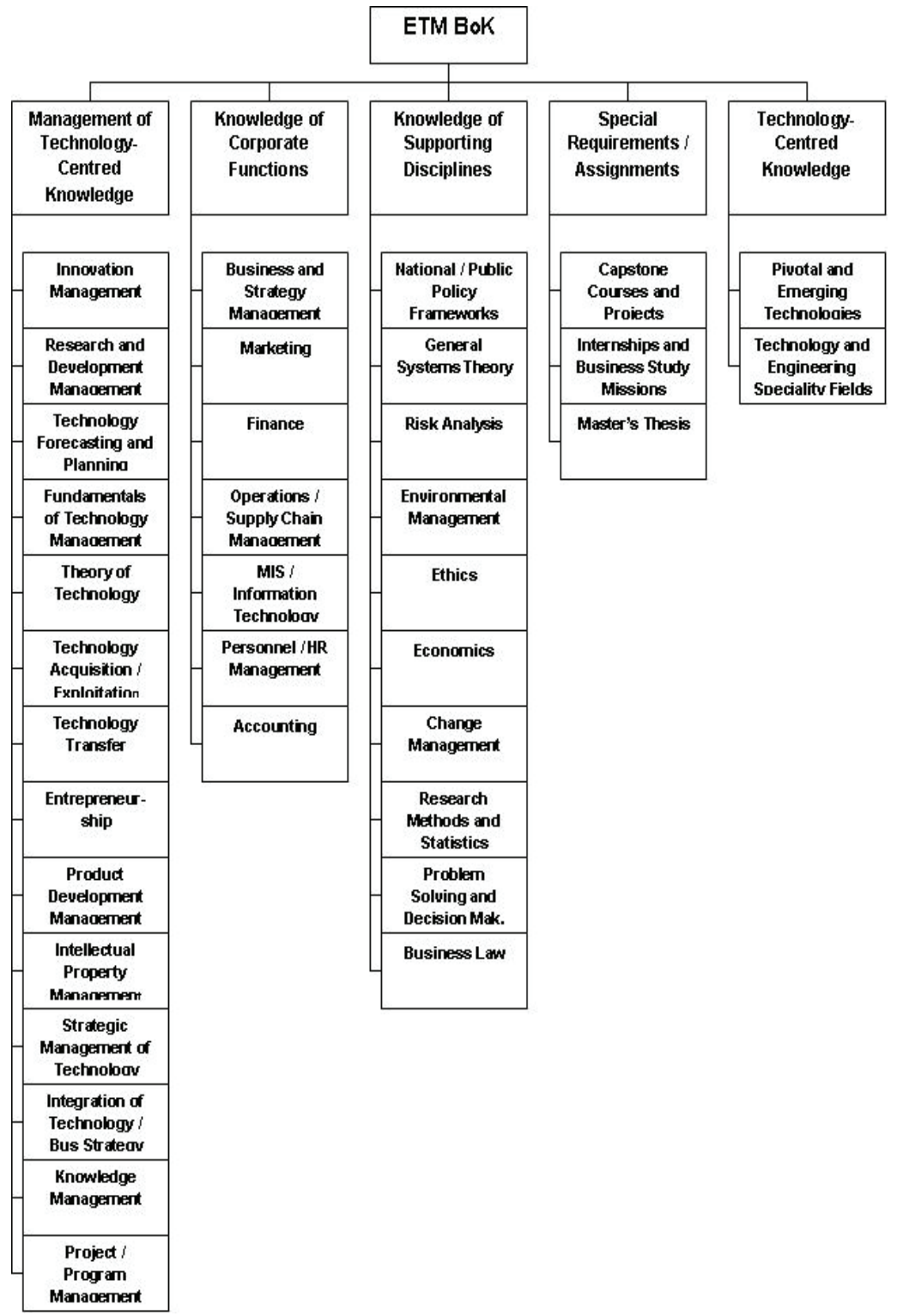

Figure 1: Framework of current Engineering and Technology Management Body-of-Knowledge 


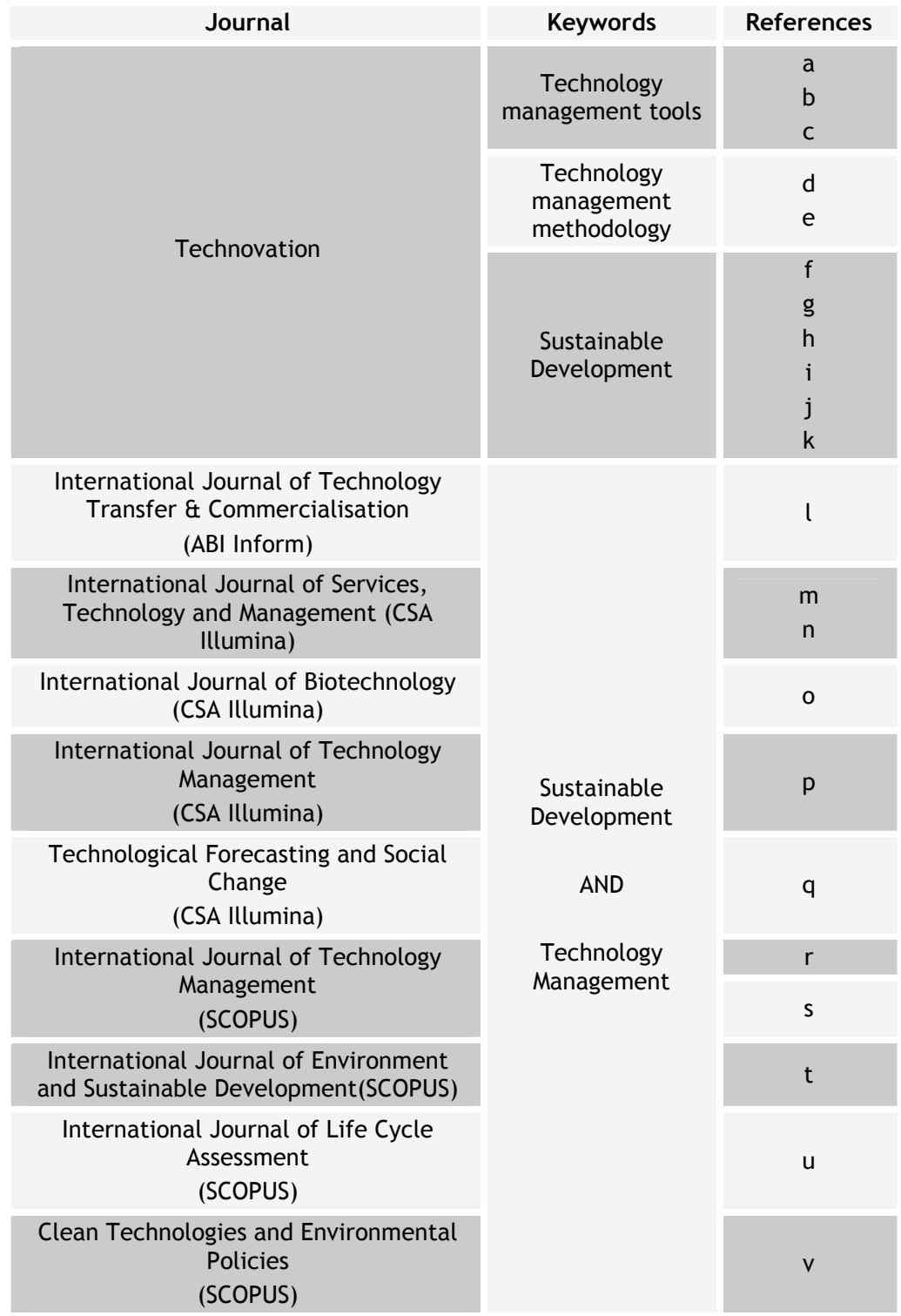

Table 1: Journals and papers relating to technology management theories and practices, and technology management orientated sustainable development 
R. Phaal, C.J.P. Farrukh, and D.R. Probert, "Technology management tools: Concept, development and application", Technovation, vol. 26, no. 3, pp. 336344, 2006.

b E. Maine, D. Probert, and M. Ashby, "Investing in new materials: A tool for technology managers”, Technovation, vol. 25, no. 1, pp. 15-23, 2005.

c T. Brady, H. Rush, M. Hobday, A. Davies, D. Probert, and S. Banerjee, "Tools for technology management: An academic perspective", Technovation, vol. 17, no. 8, pp. 417-426, 1997.

d S.-H. Liao, "Technology management methodologies and applications: A literature review from 1995 to 2003", Technovation, vol. 25, no. 4, pp. 381393, 2005.

e W.F. Jacob, and Y.H. Kwak, "In search of innovative techniques to evaluate pharmaceutical R\&D projects”, Technovation, vol. 23, no. 4, pp. 291-296, 2003.

$\mathrm{f} \quad$ A. Demaid, and P. Quintas, "Knowledge across cultures in the construction industry: Sustainability, innovation and design", Technovation, vol. 26, no. 5-6, pp. 603-610, 2006.

g Y.M. Fahmy, "Catalysis role for sustainable industrial development in Egypt with prospective", Technovation, vol. 25, no. 6, pp. 645-655, 2005.

h W. Gerstlberger, "Regional innovation systems and sustainability: Selected examples of international discussion", Technovation, vol. 24, no. 9, pp. 749758, 2004.

i C. Watanabe, R. Kondo, and A. Nagamatsu, "Policy options for the diffusion orbit of competitive innovations: An application of Lotka-Volterra equations to Japan's transition from analog to digital TV broadcasting", Technovation, vol. 23, no. 5, pp. 437-445, 2003.

j R. Harris, and A. Khare, "Sustainable development issues and strategies for Alberta's oil industry”, Technovation, vol. 22, no. 9, pp. 571-583, 2002.

k A.J.D. Lambert, and F.A. Boons, "Eco-industrial parks: Stimulating sustainable development in mixed industrial parks", Technovation, vol. 22, no. 8, pp. 471484, 2002.

l K. Momaya, "Technology management and competitiveness: is there any relationship?", International Journal of Technology Transfer and Commercialization, vol. 4, no. 4, pp. 518, 2005.

$m$ D.K. Banwet, K. Momaya, and H.K. Shee, "Competitiveness through technology management: An empirical study of the Indian software industry", International Journal of Services, Technology and Management, vol. 4, no. 2, pp. 131-155, 2003.

n P.K. Dey, S.S. Gupta, and W. Ho, "Managing technology in oil pipelines industry", International Journal of Services, Technology and Management, vol. 7, no. 2, pp. 185-210, 2006.

o W.F. Hamilton, "The biotechnology revolution: Lessons for technology management research and practice", International Journal of Biotechnology, vol. 3, no. 1-2, pp. 157-167, 2001.

p B. Bowonder, and T. Miyake, "Technology management: A knowledge ecology perspective”, International Journal of Technology Management, vol. 19, no. 7, pp. 662-684, 2000. 
q N. Sharif, "Technological dimensions of international cooperation and sustainable development", Technology Forecasting and Social Change, vol. 42, no. 4, pp. 367-383, 1992.

$r$ T.M. Khalil, and H.A. Ezzat, "Management of technology and responsive policies in a new economy", International Journal of Technology Management, vol. 32, no. 1-2, pp. 88-111, 2005.

S R. Phaal, C.J.P. Farrukh, and D.R. Probert, "A framework for supporting the management of technological knowledge", International Journal of Technology Management, vol. 27, no. 1, pp. 1-15, 2004.

t S.R. Peters, and A.-M. Coles, "Strategic innovation in sustainable technology: The case of fuel cells for vehicles", International Journal of Environment and Sustainable Development, vol. 5, no. 4, pp. 338-354, 2006.

u C. Labuschagne, and A.C. Brent, "Social indicators for sustainable project and technology life cycle management in the process industry", International Journal of Life Cycle Assessment, vol. 11, no. 1, pp. 3-15, 2006.

$v \quad J$. Korhonen, "Do we really need the debate on the natural ecosystem metaphor in technology management and sustainable development literature?", Clean Technology and Environmental Policy, vol. 7, no. 1, pp. 3341, 2004.

The IAMOT BoK survey, the ETMERC identification of related research areas, and the Technovation papers on 'technology management tools' and 'technology management methodology' were used to construct a mind map of the technology management field of knowledge (downloadable from http://www.up.ac.za/gstm) [24]. Mind maps are especially useful as support for intuitive-type research to highlight casual connections between different aspects [25]. In the technology management mind map overlaps between the IAMOT and ETMERC defined areas are shown with graphical links (left-hand side of the mind map). The linkages between defined technology management tools and methodologies, and associated applications (right-hand side of mind map), and the IAMOT and ETMERC areas are shown with numeric keys. The specific linkages between the core technology management areas and sustainable development are emphasised with shadings.

The additional literature on 'technology management' identified a conceptual framework that could be improved in the context of sustainable development. The obtained literature on 'sustainable development' was used to determine how the linkages between the core technology management areas and sustainable development occur in practice.

\section{DISCUSSION}

\subsection{An existing conceptual framework for technology management}

A conceptual framework, which is the intent of this paper, supports understanding of an issue or area of study, provides structure, communicates relationships within a system for a defined purpose, and supports decision making and action [26]. Such a framework has been introduced (see Figure 2), which is aimed at the firm level [26]. The system, within which it applies, is that of a manufacturing business. The framework aims to support understanding of how technological and commercial 
knowledge combine to support strategy, innovation and operational processes in a firm, in the context of both the internal and external environment.

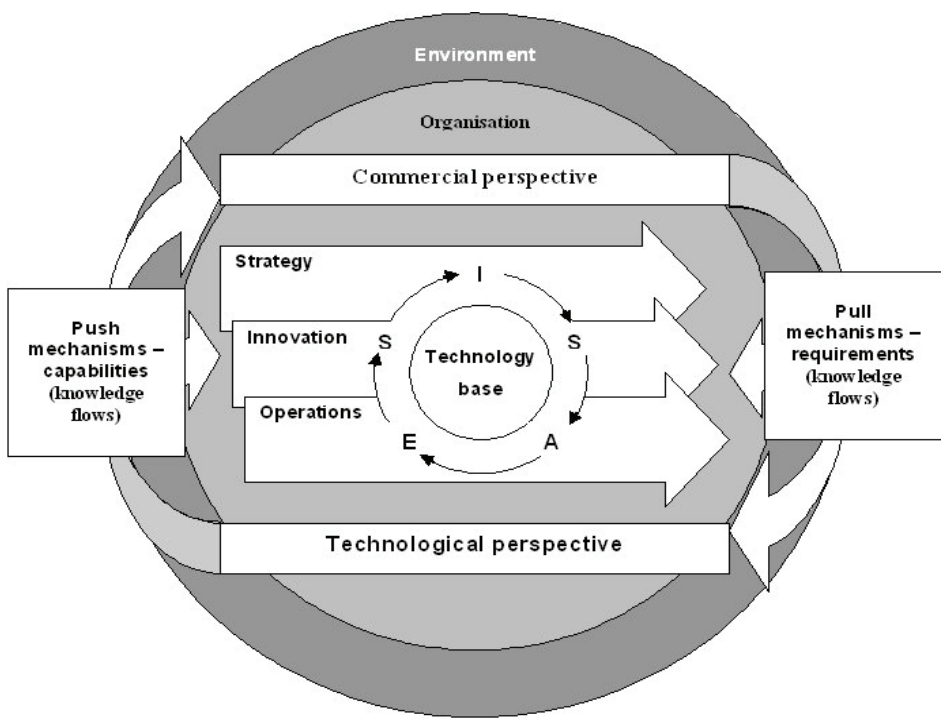

Figure 2: Conceptual technology management framework at firm level (adopted from Phaal et al. [26])

The framework emphasises the knowledge flows that must occur between commercial and technological functions of a firm, and that an appropriate balance must be obtained between push (firm capabilities) and pull (market requirement) mechanisms [26]. However, these mechanisms are defined from an internal-toexternal perspective. The framework does not accentuate the external-to-internal drivers of sustainable development, which have been noted [2]; especially for firms that develop and deploy large-scale resource-oriented technologies (see Figure 3). From a sustainable development perspective it is required to expand the 'environment' component of the conceptual framework.

Furthermore, and especially for large-scale technologies, the system must be extended beyond the firm level, i.e. the life cycle of the technology (or asset) and the life cycle of the associated product value chain must be considered $[9,27]$. Such an extended life cycle system is illustrated in Figure 4 and is described in detail elsewhere [2]. 
- Introduction of sustainable development into government policies

- Civil society xpectations

- Investors looking for evidence of good governance and effective management of risk, e.g. Dow Jones SI

- Employees

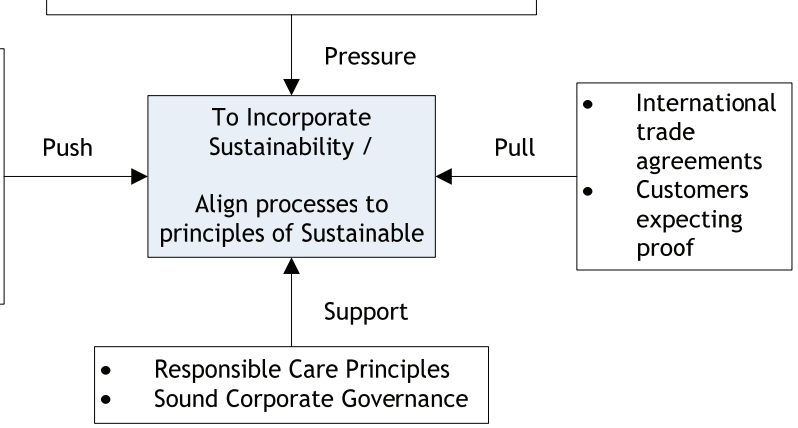

Figure 3: Drivers of sustainable development (adopted from Goede as cited in Labuschagne and Brent [2])

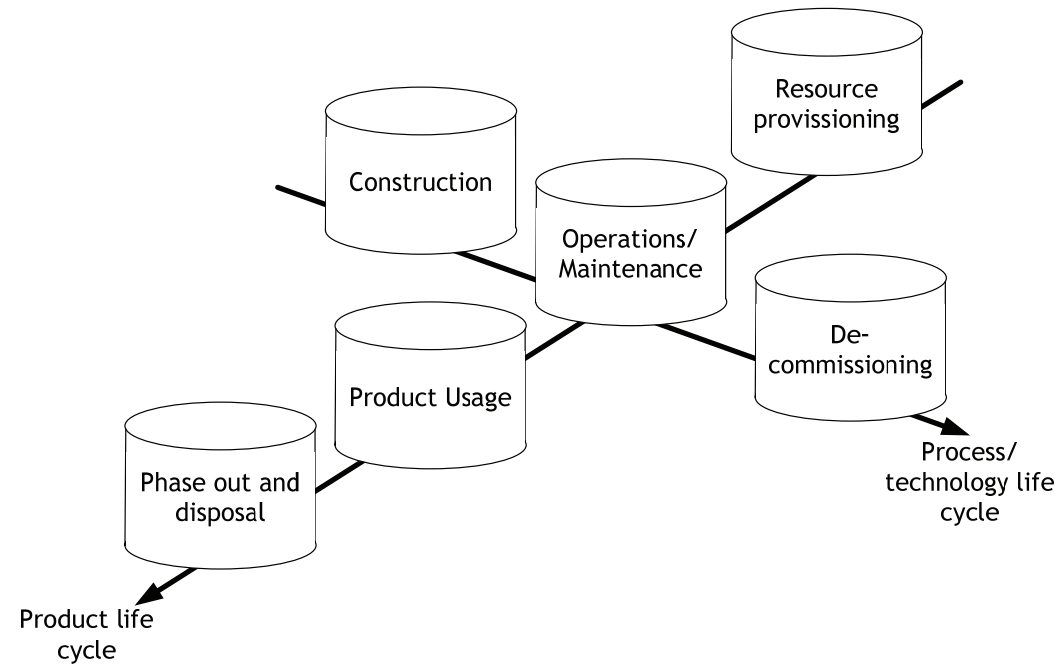

Figure 4: Life cycle system for large-scale resource-oriented technologies (adopted from Brent [9, 27]) 


\subsection{Defining a conceptual technology management framework in the context of sustainable development}

Many different criteria frameworks that aim to address the concept of sustainable development in different sectors are available in the literature. From an analysis of the different approaches, a framework has been introduced $[8,11]$ that focuses on large-scale resource-oriented technologies (see Figure 5). The framework emphasises that the operational initiatives in industry must be evaluated separately in terms of internal and external economic, social and environmental performances. However, the internal operational sustainability must also be ensured, e.g. technology management practices, and a fourth dimension of sustainable development has been suggested $[11,28]$. Therefore, it is proposed that technology management, as it relates to sustainable development, should be conceptualised as a triangular-based pyramid (see Figure 6). The three conventional dimensions of sustainable development form the base or foundation of the pyramid, and supports sustainable technology management practices at the top of the pyramid.

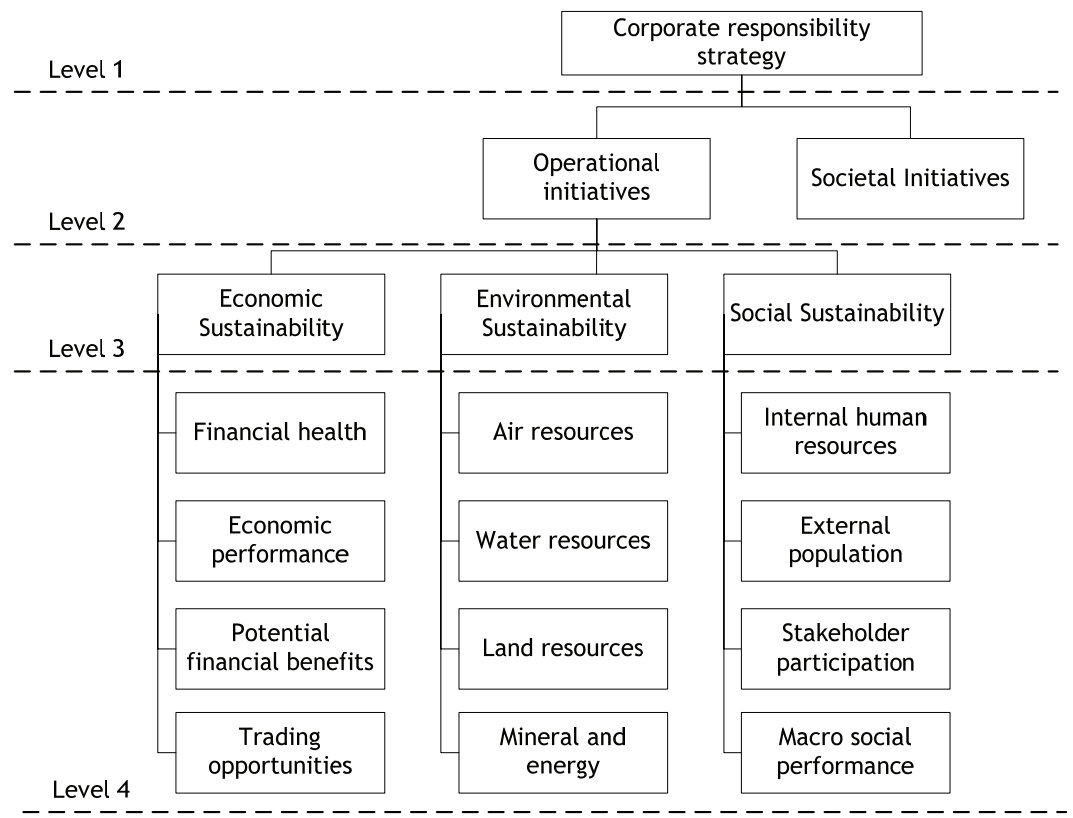

Figure 5: Framework to evaluate the sustainability performances of operational initiatives (adopted from Brent et al. [8] and Labuschagne et al. [11]) 


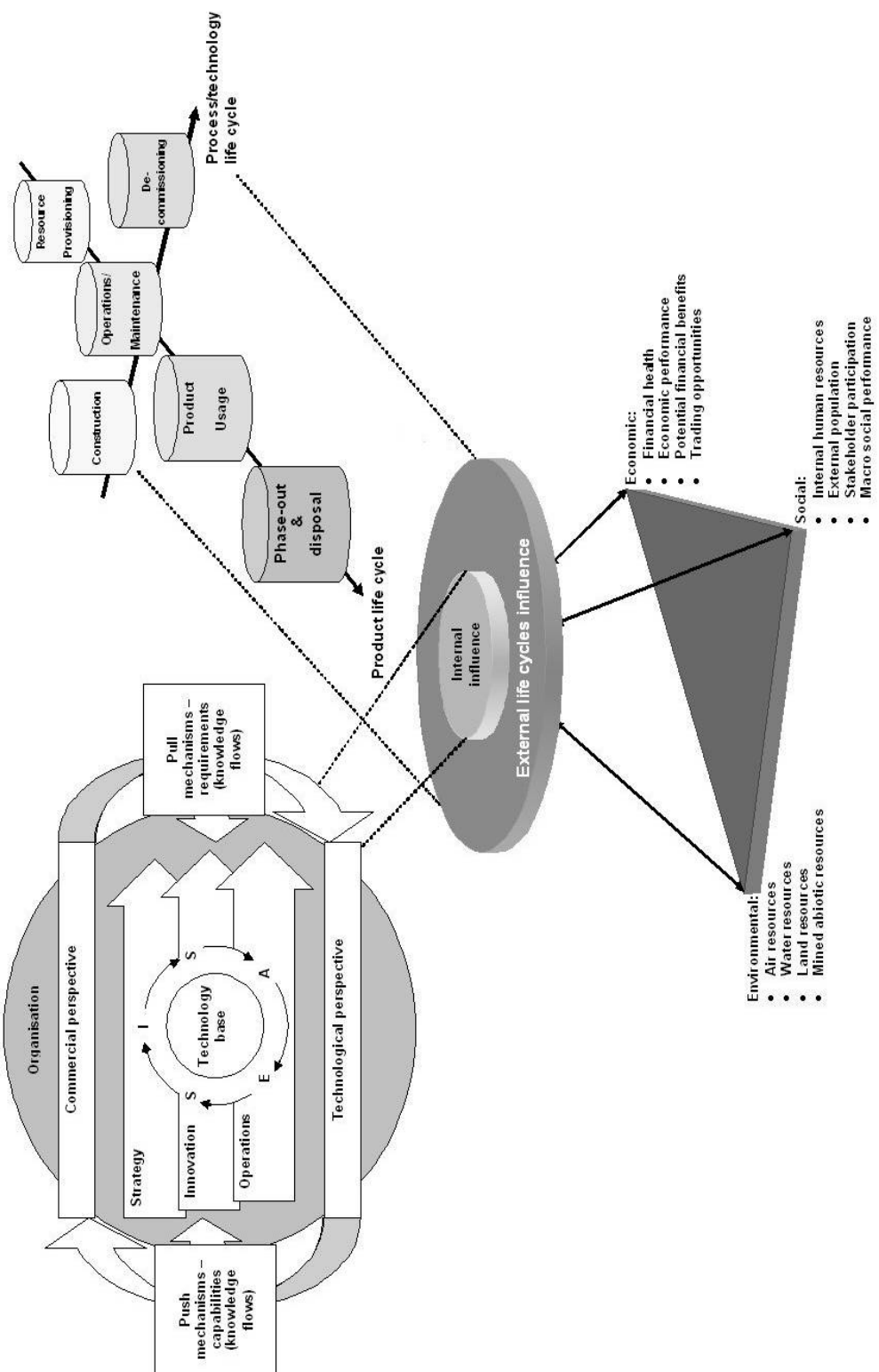

Figure 6: Conceptual framework for technology management in the sustainable development context 
The conceptual framework indicates two planes of influence. First, technology management practices (at the firm level) influence other internal operations, but sustainable development aspects, e.g. economic forces, natural resource constraints, and social behaviour, may also influence internal operations. In turn, internal operations exercise influence on different sustainable development aspects. Similarly, interaction exists between internal operational initiatives, the technology and product life cycle phases outside the firm level, and sustainable development aspects.

It has been stated that conceptual frameworks exist largely in the mind and require practical devices to 'interface' with the real world, in terms of both the development (induction) and application (deduction) of frameworks [26]. The devices, i.e. tools and methodologies, depicted on the right of the technology management mind map (Figure 2) are primarily concerned with the interfaces between two planes of the conceptual framework. This is reflected in the defined research and education focus areas of IAMOT and ETMERC. Interfaces between the planes and the sustainable development aspects have been considered in theory, albeit to a lesser extent. Table 2 summarises the obtained literature that deals with such interfaces. In these cases the technology management research and applications were mainly associated with the sub-areas of risk management and decision-analysis or support, and is highlighted in technology management mind map (dark shading).

\subsection{Emerging technology management practices and sustainable development}

It has been noted that, as a research area, technology management is extremely diverse [20]. This is emphasised in the technology management mind map. Furthermore, in the sustainable development context, technological research is viewed as one of the four branches of sustainability science [17], i.e. concentrating on the design of devices and systems to produce more social goods with less environmental harm. Sustainability science in turn can be defined as the study and integration of particular issues and aspects of radical, systemic approaches to innovation and learning for ecological and social sustainability [29]. The merger of these two fields has led to concepts such as Environmentally Sound Technologies (ESTs), i.e. technologies that have the potential for significantly improved environmental (and social) performance relative to other technologies [30].

The European Institute for Technology and Innovation Management (EITIM) states [31]: "technology management addresses the effective identification, selection, acquisition, development, exploitation and protection of technologies (product, process and infrastructural) needed to maintain a market position and business performance in accordance with the company's objectives". For ESTs, the emphasis is not only on the firm level, but also on the regional, national and international levels [30]. This again stresses the requirement to expand the technological system that is managed, as is shown in the conceptual model (Figure 6), and an adaptation to the EITIM definition is proposed, i.e. technology management addresses the effective identification, selection, acquisition, development, exploitation and protection of technologies (product, process and infrastructure) needed to sustain the competitive advantage of regional sectors in accordance with the sector, regional, national and international sustainable development objectives. A number of cases 
have been documented in literature supporting the proposed definition of technology management (Table 3).

\section{Ref. Description of paper focus}

The uncertainty associated with the changing legal and ethical imperatives of sustainable development and the related additional complexity of knowledge management in a specific sector; the similarities between the fields of sustainable development and risk are specifically highlighted.

Technological trends in specific sectors due to sustainable development

b pull and push drivers with a subsequent strategic plan and policy advice for decision-makers.

\begin{tabular}{|c|c|}
\hline C & $\begin{array}{l}\text { Systematic design of regional innovation systems for policy support, } \\
\text { whereby the multidimensional aspects of sustainable development aspects } \\
\text { are considered for effective, sustainable knowledge transfer in networks. }\end{array}$ \\
\hline$d$ & $\begin{array}{c}\text { Policy options to substitute technologies in a specific sector for } \\
\text { competitive advantage; sustainable development, from an ecosystem } \\
\text { perspective, is used as basis to formulate an approach for competitive } \\
\text { innovation. }\end{array}$ \\
\hline e & $\begin{array}{l}\text { Strategy development for a specific sector due to sustainability pull and } \\
\text { push drivers; sustainable development risk are identified that decision- } \\
\text { makers must consider for the long-term survival of the sector. }\end{array}$ \\
\hline$f$ & $\begin{array}{l}\text { Societal and environmental problems related to mixed industrial parks, i.e. } \\
\text { an extension of the industrial symbiosis concept, are identified, and solu- } \\
\text { tions proposed to ensure the continuity and sustainability of these parks. }\end{array}$ \\
\hline g & $\begin{array}{c}\text { Strategic management of technology to sustain the competitiveness of } \\
\text { organisations; sustainable development is synonymous with management } \\
\text { performance and competitiveness in terms of productivity, growth, returns } \\
\text { and market capitalisation. }\end{array}$ \\
\hline
\end{tabular}

Technological competitiveness must be achieved to realise sustainable

$\mathrm{h}$ development, and the internal processes and assets that derive performances are important for decision-makers; no emphasis is placed on external drivers.

\begin{tabular}{|c|c|}
\hline i & $\begin{array}{c}\text { Defining characteristics of technological trends and response firms to } \\
\text { propose changes in management practices for effective technology } \\
\text { transfer. }\end{array}$ \\
\hline j & $\begin{array}{c}\text { Combining knowledge management and ecosystem theory concepts to } \\
\text { sustain competitive advantage in an uncertain business context. }\end{array}$ \\
Increasing international cooperation to ensure the advancement and \\
spread of technology that is economically efficient, commercially \\
attractive, and environmentally sound, and that leads to self-reliance; \\
technology-oriented policies are addressed.
\end{tabular}

Globalisation, competitiveness, and the risk of marginalisation of developing nations; responses in public policy are highlighted, with emphasis on human resource development.

Table 2: Current technology management research and applications in relation to sustainable development 
a A. Demaid, and P. Quintas, "Knowledge across cultures in the construction industry: Sustainability, innovation and design", Technovation, vol. 26, no. 5-6, pp. 603-610, 2006.

b Y.M. Fahmy, "Catalysis role for sustainable industrial development in Egypt with prospective”, Technovation, vol. 25, no. 6, pp. 645-655, 2005.

c W. Gerstlberger, "Regional innovation systems and sustainability: Selected examples of international discussion", Technovation, vol. 24, no. 9, pp. 749758, 2004.

d C. Watanabe, R. Kondo, and A. Nagamatsu, "Policy options for the diffusion orbit of competitive innovations: An application of Lotka-Volterra equations to Japan's transition from analog to digital TV broadcasting", Technovation, vol. 23, no. 5, pp. 437-445, 2003.e R. Harris, and A. Khare, "Sustainable development issues and strategies for Alberta's oil industry", Technovation, vol. 22, no. 9, pp. 571-583, 2002.

$f \quad$ A.J.D. Lambert, and F.A. Boons, "Eco-industrial parks: Stimulating sustainable development in mixed industrial parks", Technovation, vol. 22, no. 8, pp. 471484, 2002.

g K. Momaya, "Technology management and competitiveness: is there any relationship?", International Journal of Technology Transfer and Commercialization, vol. 4, no. 4, pp. 518, 2005.

h D.K. Banwet, K. Momaya, and H.K. Shee, "Competitiveness through technology management: An empirical study of the Indian software industry", International Journal of Services, Technology and Management, vol. 4, no. 2, pp. 131-155, 2003.

i W.F. Hamilton, "The biotechnology revolution: Lessons for technology management research and practice", International Journal of Biotechnology, vol. 3, no. 1-2, pp. 157-167, 2001.

j B. Bowonder, and T. Miyake, "Technology management: A knowledge ecology perspective", International Journal of Technology Management, vol. 19, no. 7, pp. 662-684, 2000.

k N. Sharif, "Technological dimensions of international cooperation and sustainable development", Technology Forecasting and Social Change, vol. 42, no. 4, pp. 367-383, 1992.

I T.M. Khalil, and H.A. Ezzat, "Management of technology and responsive policies in a new economy", International Journal of Technology Management, vol. 32, no. 1-2, pp. 88-111, 2005. 
Ref.

Description of paper focus

an accepted strategy for medium- and large-scale industry sectors
in less developed countries is identified as capability building for
technology options based on technology transfer with the aim of
achieving competitiveness in international markets; the
'intermediate technology' approach is also introduced for the
clustering of small-scale developments in sectors of the third-
world.

b

A strategy is suggested that focuses on selected niches with the aim of integrating the innovation dimension into a policy for specific technology options; the growth in successful applications would lead to the development of new industry sectors in countries.

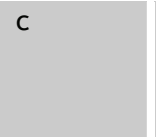

Strategies for enhancing the flexibility of technological systems, which is increasingly required because of uncertainties and fast developments, to promote alternative technology options and change in industry sectors.

d

A more informed analysis of technological innovation, and associated options, is suggested for discussions about the future direction of industrial society and subsequent strategies that is required to adapt specific sectors to sustainability requirements.

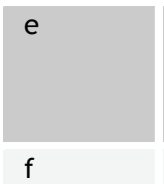

Mechanisms are explored for transferring technologies into sectors of developing countries, by first characterising technologies, and then identifying strategies for organisational development to facilitate such transfers.

Policy issues are discussed that need to be addressed to enhance the effectiveness of the transfer and innovation of specific technologies in sectors of developing countries.

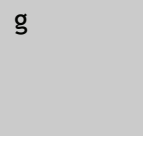

Analysis and strategy of how new technologies can be delivered in specific sectors of developing countries; specifically the transfer of knowledge between sectors and between innovation processes is addressed.

h Adaptation of a technology transfer model for application at company, network and government level for symbiotic strategy formulation.

Table 3: Emerging technology management research and applications in relation to sustainable development

a R.H. Grieve, "Appropriate technology in a globalizing world", International Journal of Technology Management and Sustainable Development, vol. 3, no. 3, pp. 173-187, 2004.

b T.D. Tsoutsos, and Y.A. Stamboulis, "The sustainable diffusion of renewable energy technologies as an example of innovation-focused policy", Technovation, vol. 25, no. 7, pp. 753-761, 2005. 
C J.M.C. Knot, J.C.M. van den Ende, and P.J. Vergragt, "Flexibility strategies for sustainable technology development”, Technovation, vol. 21 , no. 6, pp. 335343, 2001.

d A.-M. Coles, and S.R. Peters, "Sustainable development, global innovation and advanced technologies: The case of fuel cells", International Journal of Environmental Technology and Management, vol. 3, no. 3/4, pp. 278-289, 2003, In: "Alternative energy sources", Fuel and Energy Abstracts, vol. 46, no. 1, pp. 26, 2005.

e J. Bessant, and D. Francis, "Transferring soft technologies: Exploring adaptive theory", International Journal of Technology Management and Sustainable Development, vol. 4, no. 2, pp. 93-112, 2005.

f C. Malairaja, and G. Zawdie, “The 'black box' syndrome in technology transfer and the challenge of innovation in developing countries: The case of international joint ventures in Malaysia", International Journal of Technology Management and Sustainable Development, vol. 3, no. 3, pp. 233-251, 2004.

g S. Ayele, "Biotechnology generation, delivery and adoption: The case of Bt biopesticide in Eqypt", International Journal of Technology Management and Sustainable Development, vol. 4, no. 2, pp. 75-91, 2005.

h S. Harris, and C. Pritchard, "Industrial Ecology as a learning process in business strategy”, Progress in Industrial Ecology, vol. 1, no. 1/2/3, pp. 89-111, 2004.

Table 3 further shows that the literature on technology management and sustainable development increasingly deals with three main issues:

- Integrated strategies across companies, sectors, regions, and, in some cases, across countries.

- Selection of appropriate technological options across companies, sectors, regions and countries.

- The transfer of technologies (and knowledge) across companies, sectors, regions and countries.

A focal point of these three issues is that of technology assessment or evaluation, which also forms part of other technology frameworks and methodologies (of the technology management mind map). Technology evaluation is one of the most significant techniques in an innovation function, such as technology transfer, and it is best utilized in screening new ideas, assessing innovative or not innovative technologies; it is a set of principles, methods and techniques or tools for effective assessing the potential value of a technology and its contribution to a company's competitiveness and profitability [32]. Models [33] and metrics [34] have been introduced to assist the technology assessment process at firm level. The following statements have been made with regards to the ongoing development of metrics [34]:

- $\quad$ Technology is not judged by its existence alone, nor is its mere existence a sufficient condition for successful usage.

- We cannot evaluate technology unless and until we put it in the context of social (and environmental) and economic phenomena. 
Technology is not defined and evaluated by what it is, but by the criteria outside itself - by its actual and potential users.

These statements support the system expansion component of the conceptual framework (Figure 6), and the notion of sustainability performance indicators that have been proposed for technology management purposes [9, 11, 27].

\subsection{Sustainability performance indicators for technology management}

General technical, economic, environmental and social indicators have been proposed for technology transfer evaluations [35]. For large-scale resource-oriented technologies specific sustainability indicators have subsequently been developed, which are described in detail elsewhere [36, 37, 28].

Although the applications of these indicators do attempt to follow a holistic approach, constraints have been noted where sustainability information is required from parts of the expanded system that is not controlled by the particular technology management decision-makers. Especially in the initial research and development phases of technology management, a set of principles, methods and techniques or tools must be established for effectively assessing the potential value of a technology and its contribution to sustainable development during the market uptake phases of its life cycle (see Figure 7).

\section{CONCLUSIONS}

The turn of the millennium has seen increasing efforts to align technological research with the emerging field of sustainability science [38]. However, the field of science and technology for sustainability is in its infancy [39]. From the review of the literature summarised in this paper, it is concluded that sustainability aspects are not addressed adequately in technology management theories and practices.

A conceptual framework is subsequently proposed, which is based on an existing framework for technology management, but as the field relates to sustainable development. The framework defines the context better in which sustainable technology management may occur, although the framework has yet to be verified through practical applications. The framework indicates that an expanded system perspective is required, that not only includes the respective technological, operational and business life cycles across companies, regions and countries, but also the dynamic interaction between macro, meso, and micro economies, societies at large, and the natural environment, as perceived by sustainability science. A modification to the definition of technology management has subsequently been proposed. 


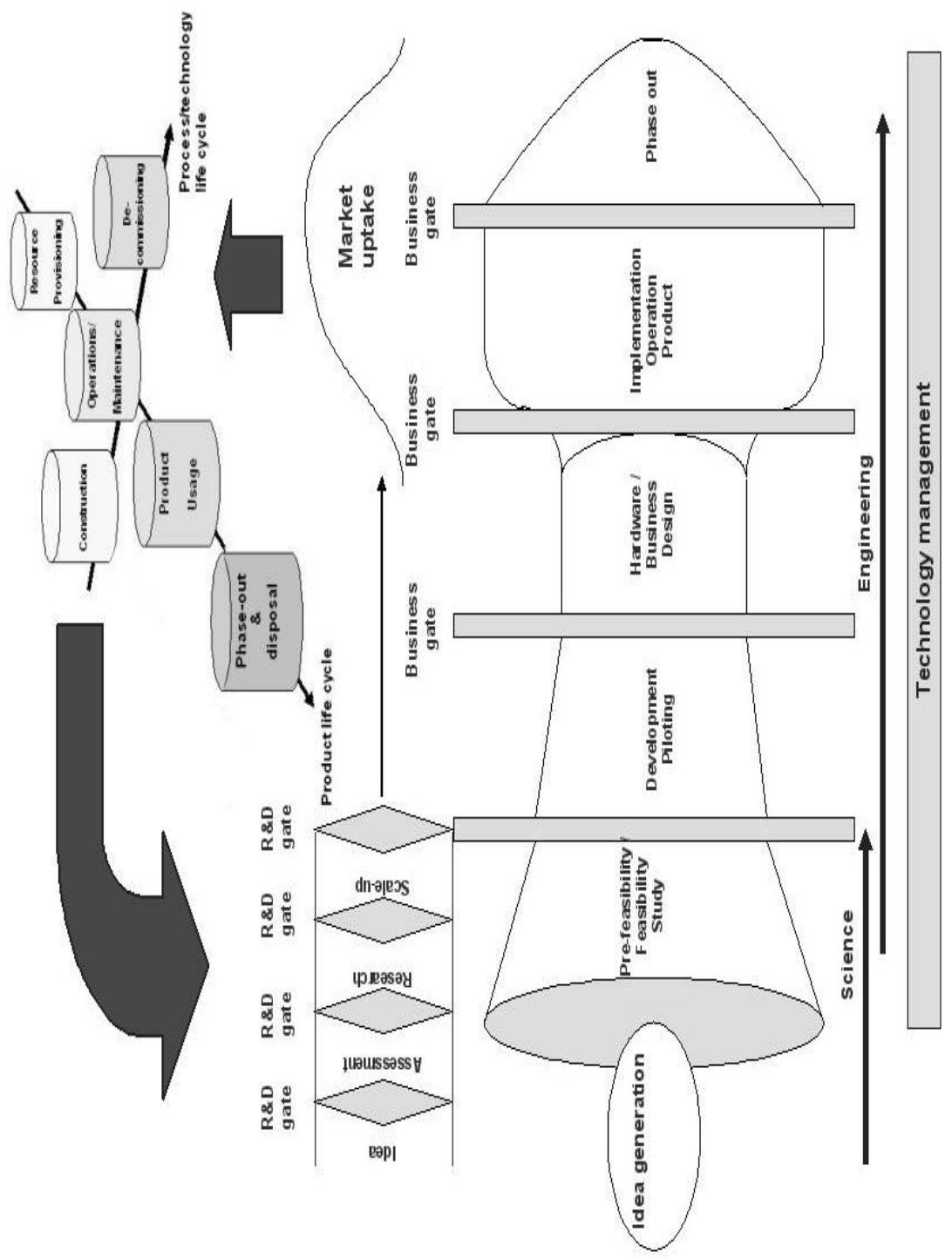

Figure 7: Technology life cycle interventions and associated evaluated systems 
The technology management field is extremely diverse, which is illustrated through an introduced mind map. However, emerging technology management practices related to sustainable development do emphasise the focus on technology strategy, selection and transfer, especially between developed and emerging economies. At the core of these issues lies technology assessment, which also forms part of other technology frameworks and methodologies. As a departure point for further research in terms of incorporating the concept of sustainable development into the technology management field of knowledge, it is therefore recommended to concentrate on the development of technology assessment methods, as they are used in technology management practices, which incorporate the intrinsic modelling that is researched in the field of sustainability science. To this end, the modification of the available Technology Balance Sheet, Income Statement and Space Map analytical techniques are currently being investigated, with specific emphasis on the initial research and development phases of technology management.

Ultimately, the challenge lies in the formation and coordination of transdisciplinary research teams [40] that are required to reach truly sustainable technology management practices.

\section{REFERENCES}

[1] Mebratu, D. 1998. Sustainability and sustainable development: Historical and conceptual review. Environmental Impact Assessment Review, 18, pp. 493520.

[2] Labuschagne, C. \& Brent, A.C. 2005. Sustainable project life cycle management: The need to integrate life cycles in the manufacturing sector. International Journal of Project Management, 23(2), pp. 159-168.

[3] World Bank. What is Sustainable Development. Website: http://www.worldbank.org/depweb/english/sd.html, accessed 2 May 2007.

[4] Briassoulis, H. 2001. Sustainable development and its indicators: Through a (planner's) glass darkly. Journal of Environmental Planning and Management, 44(3), pp. 409-427.

[5] Azapagic, A. \& Perdan, S. 2000. Indicator of sustainable development for industry: A general framework. Transactions IchemE, 78(b), pp. 243-261.

[6] United Nations Commission on Sustainable Development (UNCSD). Indicators of sustainable development: Guidelines and methodologies. Website: http://www.un.org/esa/sustdev/isd.htm, accessed 2 May 2007.

[7] Labuschagne, C., Brent, A.C. \& Claasen, S.J. 2005. Environmental and social impact considerations for sustainable project life cycle management in the process industry. Corporate Social Responsibility and Environmental Management, 12(1), pp. 38-54.

[8] Brent, A.C., van Erck, R.P.G. \& Labuschagne, C. 2006. Sustainability Cost Accounting: Part 1 - A monetary procedure to evaluate the sustainability of 
technologies in the South African process industry. South African Journal of Industrial Engineering, 17(2), pp. 35-51.

[9] Brent, A.C., van Erck, R.P.G. \& Labuschagne, C. 2007. Sustainability Cost Accounting: Part 2 - A case study to demonstrate and assess the introduced monetary procedure to evaluate the sustainability of technologies in the South African process industry. South African Journal of Industrial Engineering, 18(1), pp. 1-17.

[10] Robèrt, K.-H., Schmidt-Bleek, B., Aloisi de Larderel, J., Basile, G., Jansen, J.L, Kuehr, R., Price Thomas, P., Suzuki, M., Hawken, P. \& Wackernagel, M. 2002. Strategic sustainable development: Selection, design and synergies of applied tools. Journal of Cleaner Production, 10, pp. 197214.

[11] Labuschagne, C., Brent, A.C. \& van Erck, R.P.G. 2005. Assessing the sustainability performances of industries. Journal of Cleaner Production, 13(4), pp. 373-385.

[12] Hanley, N., Shogren, J. \& White, B. 1997. Environmental economics in theory and practice. Palgrave Macmillan, United Kingdom.

[13] Rennings, K. \& Wiggering, H. 1997. Steps towards indicators of sustainable development: Linking economic and ecological concepts. Ecological Economics, 20, pp. 25-36.

[14] Atkinson, G. 2000. Measuring corporate sustainability. Journal of Environmental Planning and Management, 43(2), pp. 235-252.

[15] Brent, A.C., Heuberger, R. \& Manzini, D. 2005. Evaluating projects that are potentially eligible for Clean Development Mechanism (CDM) funding in the South African context: A case study to establish weighting values for sustainable development criteria. Environmental and Development Economics, 10(5), pp. 631-649.

[16] Coles, A.-M. \& Peters, S.R. 2003. Sustainable development, global innovation and advanced technologies: The case of fuel cells. International Journal of Environmental Technology and Management, 3(3/4), pp. 278-289, In: 2005. "Alternative energy sources", Fuel and Energy Abstracts, 46(1), pp. 26.

[17] Kates, R.W., Clark, W.C., Corell, R., Hall, J.M., Jaeger, C.C., Lowe, I., McCarthy, J.J., Schellnhuber, H.J., Bolin, B., Dickson, N.M., Faucheux, S., Gallopin, G.C., Grübler, A., Huntley, B., Jäger, J., Jodha, N.S., Kasperson, R.E., Mabogunje, A., Matson, P., Mooney, H., Moore III, B., O'Riordan, T. \& Svedin, U. 2001. Sustainability science. Science, 292 (5517), pp. 641-642.

[18] Murto, P. Competitive equilibrium and investments in a growing market: The choice between small- and large-scale electricity production. Reykholt: 
Annual Meeting of the Energy Economics Subprogram of the NERI, 2000, Website: http://www.ioes.hi.is/rammi4.htm, accessed 2 May 2007.

[19] Cooney, R. 2004. The precautionary principle in biodiversity conservation and natural resource management: An issue paper for policy-makers, researchers and practitioners. IUCN Policy and Global Change Series, 2, The World Conservation Union, Cambridge.

[20] Pilkington, A. \& Teichert, T. 2006. Management of Technology: Themes, concepts and relationships. Technovation, 26(3), pp. 288-299.

[21] International Association for Management of Technology (IAMOT). IAMOT Body-of-Knowledge (BoK). Website: http://www.iamot.org/bok/, accessed 2 May 2007.

[22] Portland State University. ETM study: List of current responses. Website: http://www.etm.pdx.edu/survey/results.asp, accessed 2 May 2007.

[23] Engineering and Technology Management Education and Research Council (ETMERC). Main research areas. Website:

http://www.etmerc.org/research_areas.htm, accessed 2 May 2007.

[24] University of Pretoria. Related links: Technology Management Mindmap. Website: http://www.up.ac.za/gstm, accessed 2 May 2007.

[25] Monaghan, P. 2003. Interdisciplinary research design. School for New Learning, DePaul University, Website:

http://snl.depaul.edu/contents/current/forms/interdisciplinary_research_d esign.doc, accessed 2 May 2007.

[26] Phaal, R., Farrukh, C.J.P. \& Probert, D.R. 2004. A framework for supporting the management of technological knowledge. International Journal of Technology Management, 27(1), pp. 1-15.

[27] Brent, A.C., van Erck, R.P.G. \& Labuschagne, C. 2005. A sustainability cost accounting methodology for technology management in the process industry. Conference Proceedings of the International Association for the Management of Technology (IAMOT), Vienna, Austria.

[28] Mulder, J. \& Brent, A.C. 2006. Selection of sustainable agriculture projects in South Africa: Case studies in the LandCare programme. Journal of Sustainable Agriculture, 28(2), pp. 55-84.

[29] Struyf, I.L.R. 2003. Inter-organizational learning for sustained competitiveness and ecological sustainability - the case of beta-testing activities of alternative-fuel, fuel cell-driven public transport buses. Doctoral research paper, Erasmus Centre for Sustainability and Management, Erasmus University, Rotterdam, the Netherlands. 
[30] International Environmental Technology Centre (IETC). 2003. Environmentally Sound Technologies and Sustainable Development. Division of Technology, Industry and Economics United Nations Environment Programme, Website: http://www.unep.or.jp/ietc/knowledge, accessed 2 May 2007.

[31] European Institute for Technology and Innovation Management (EITM). Our purpose and mission. Website:

http://www-eitm.eng.cam.ac.uk/index.html, accessed 2 May 2007.

[32] Bakouros, Y. 2005. Technology evaluation. Portland International Conference for the Management of Engineering and Technology (PICMET), Portland, Oregon.

[33] Pretorius, M.W. \& de Wet, G. 2000. A model for the assessment of new technology for the manufacturing enterprise. Technovation, 20(1), pp. 3-10.

[34] Geisler, E. 2002. The metrics of technology evaluation: Where we stand and where we should go from here. International Journal of Technology Management, 24(4), pp. 341-374.

[35] Dunmade, I. 2002. Indicators of sustainability: Assessing the suitability of a foreign technology for a developing economy. Technology in Society, 24(4), pp. 461-471.

[36] Brent, A.C. \& Visser, J.K. 2005. An Environmental Performance Resource Impact Indicator for Life Cycle Management in the manufacturing industry. Journal of Cleaner Production, 13(6), pp. 557-565.

[37] Labuschagne, C. \& Brent, A.C. 2006. Social indicators for sustainable project and technology life cycle management in the process industry. International Journal of Life Cycle Assessment, 11(1), pp. 3-15.

[38] Clark, W.C. \& Dickson, N.M. 2003. Sustainability science: The emerging research program. Proceedings of the National Academy of Sciences of the United States of America, 100 (14), pp. 8059-8061, Available:

http://www.pnas.org/cgi/content/full/100/14/8059.

[39] American Association for the Advancement of Science (AAAS). FORUM: Science and Innovation for Sustainable Development. Website: http://sustsci.aaas.org/, accessed 2 May 2007.

[40] Pohl, C. 2001. How to bridge between natural and social sciences? An analysis of three approaches to transdisciplinary from the Swiss and German field of environmental research. Natures Sciences Societes, 9(3), pp. 37-46. 